University of Nebraska - Lincoln

DigitalCommons@University of Nebraska - Lincoln

1984

\title{
Habitat Use by Migrant Sandhill Cranes in Nebraska
}

\author{
Gary Krapu \\ USGS Northern Prairie Wildlife Research Center, gkrapu@usgs.gov \\ Douglas Facey \\ USGS Northern Prairie Wildlife Research Center \\ Erik Fritzell \\ USGS Northern Prairie Wildlife Research Center \\ Douglas Johnson \\ USGS Northern Prairie Wildlife Research Center, Douglas_H_Johnson@usgs.gov
}

Follow this and additional works at: https://digitalcommons.unl.edu/usgsnpwrc

Part of the Other International and Area Studies Commons

Krapu, Gary; Facey, Douglas; Fritzell, Erik; and Johnson, Douglas, "Habitat Use by Migrant Sandhill Cranes in Nebraska" (1984). USGS Northern Prairie Wildlife Research Center. 59.

https://digitalcommons.unl.edu/usgsnpwrc/59

This Article is brought to you for free and open access by the US Geological Survey at DigitalCommons@University of Nebraska - Lincoln. It has been accepted for inclusion in USGS Northern Prairie Wildlife Research Center by an authorized administrator of DigitalCommons@University of Nebraska - Lincoln. 


\section{HABITAT USE BY MIGRANT SANDHILL CRANES IN NEBRASKA}

GARY L. KRAPU, U.S. Fish and Wildlife Service, Northern Prairie Wildlife Research Center, Jamestown, ND 58401 DOUGLAS E. FACEY, 1 U.S. Fish and Wildlife Service, Northern Prairie Wildife Research Center, Jamestown, ND 58401 ERIK K. FRITZELL, ${ }^{2}$ U.S. Fish and Wildlife Service, Northern Prairie Wildlife Research Center, Jamestown, ND 58401 DOUGLAS H. JOHNSON, U.S. Fish and Wildlife Service, Northern Prairie Wildlife Research Center, Jamestown, ND 58401

Abstract: The principal spring staging areas of the midcontinent population of sandhill cranes (Grus canadensis) are along the Platte and North Platte rivers in south-central Nebraska. Most of these lands are privately owned and managed for corn and cattle production. Diurnal habitat use by radio-tagged cranes was primarily in cropland (55\%), native grassland (28\%), and tame hayland (15\%). Ninety-nine percent of the cropland use was in cornfields; $55 \%$ as grazed stubble, $36 \%$ as disced, cultivated, and plowed stubble, $7 \%$ as ungrazed stubble, and $1 \%$ unclassified. Grazed pastures accounted for $93 \%$ of the grassland locations and mowed alfalfa fields $77 \%$ of the tame hayland locations. Other habitats were seldom used. Time budget analyses indicated that cranes, while in croplands, grasslands, and haylands, spent 35, 36, and 50\% of the time foraging, respectively. Cranes roosted in the shallows and on nearby sandbars of about $111 \mathrm{~km}$ of river channel. Cranes usually roosted where the channel was at least $150 \mathrm{~m}$ wide and avoided stretches narrower than $50 \mathrm{~m}$. Height of woody vegetation along shorelines and on islands influenced where cranes roosted when unobstructed channel width was less than $150 \mathrm{~m}$; bridges or roads adjacent to the channel also reduced use by about half. Management recommendations are made for maintaining suitable habitat for sandhill cranes on their staging areas in Nebraska.

J. WILDL. MANAGE. 48(2):407-417

Approximately one-half million sandhill cranes (four-fifths of the continental population) gather annually along the Platte and North Platte rivers in Nebraska during March and early April while en route to their breeding grounds in central and arctic Canada, Alaska, and Siberia (U.S. Fish and Wildl. Serv., unpubl. data). Water developments in the upper Platte River Basin during this century have drastically reduced flows, causing major changes in channel width in the Big Bend reach (Williams 1978) where most of the cranes gather. Extensive encroachment by woody vegetation has accompanied channel shrinkage (Currier 1982), and proposed developments would cause additional habitat degradation and loss (Krapu et al. 1982), raising concern for the well-

\footnotetext{
${ }^{1}$ Present address: Department of Zoology, University of Georgia, Athens, GA 30602

${ }^{2}$ Present address: School of Forestry, Fisheries and Wildlife, 112 Stephens Hall, University of MissouriColumbia, Columbia, MO 65211.
}

being of the midcontinent sandhill crane population.

A lack of detailed information on habitat conditions or habitat requirements of the crane population during the spring staging period prompted the U.S. Fish and Wildlife Service to initiate extensive studies beginning in 1978. In this paper we describe (1) land use and other characteristics of crane staging areas along the Platte and North Platte rivers, (2) diurnal habitat-use patterns of sandhill cranes in relation to land use and habitat availability, and (3) nocturnal habitat use relative to existing channel conditions along the Platte and North Platte rivers.

We thank P. J. Currier and C. A. Faanes for critically reviewing this manuscript; $\mathrm{L}$. M. Mechlin and C. W. Shaiffer for their assistance in capturing sandhill cranes for telemetry studies; M. A. Hay, D. G. Jorde, and $\mathrm{W}$. Norling for assistance in both crane trapping and collecting telemetry data; and B. Gehring for interpreting aerial photography of staging areas. Apprecia- 


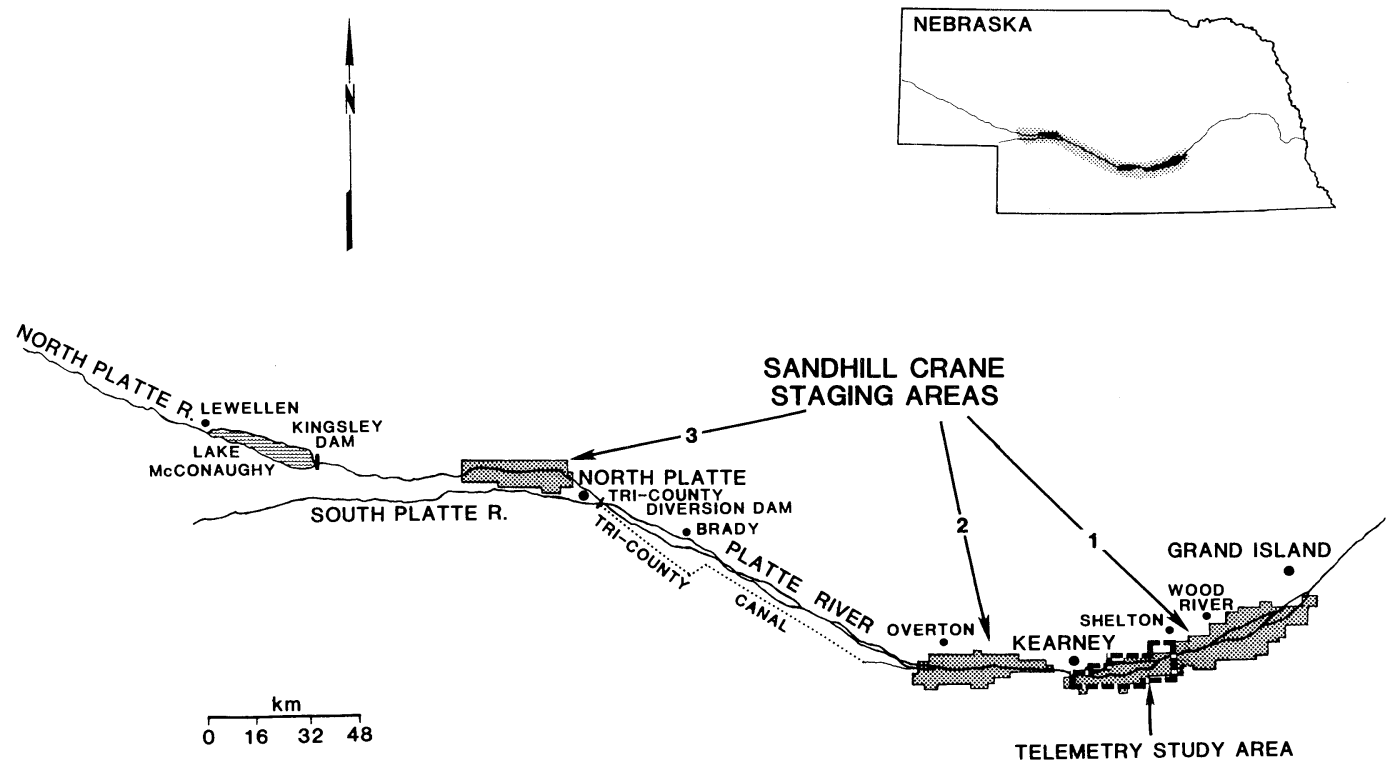

Fig. 1. Sandhill crane studies were conducted along the Platte and North Platte rivers between Kingsley Dam and Grand Island, Nebraska.

tion is expressed to U.S. Fish and Wildl. Serv. personnel in Nebraska who aided our study. In particular, we thank C. R. Frith, Supervisor of the Ecol. Serv. Off. at Grand Island, Nebr., and his staff. We are grateful to Platte River Valley landowners for allowing us access to their properties. We are appreciative of The Natl. Aud. Soc. and, in particular, R. Wicht, former manager of the Lillian Annette Rowe Sanctuary near Gibbon, Nebr., for assistance. We thank M. I. Meyer and C. W. Shaiffer for preparing the figures and T. L. Fercho and D. J. Reimers for typing support.

\section{STUDY AREA AND METHODS}

The locations of staging areas (Fig. 1) were delineated in conjunction with population surveys conducted between Lewellen and Grand Island in March 1979 (Faanes and Frank 1982). Habitat composition and land-use characteristics were identified for the three major crane stag- ing areas from color aerial photography (1:24,000) taken in August 1979. Habitats were classified as cropland, native grassland (primarily livestock pastures), tame hayland (mostly alfalfa), present channel, former channel, and other. The latter category included wildlife areas, highway rights-of-way, sand and gravel developments, businesses, residences, farmsteads, feedlots, and woodlots. General classes of land ownership were ascertained from county plat books. Area measurements were made with a Numonics Model 1224 electronic digitizer. (Reference to trade name does not imply Government endorsement of commercial products.)

Diurnal habitat use by sandhill cranes was determined by monitoring radiotagged cranes during late February, March, and early April on a $253-\mathrm{km}^{2}$ area between Kearney and Shelton, Nebraska (Fig. 1). The area was a mosaic of several Platte River Valley habitat types and was 


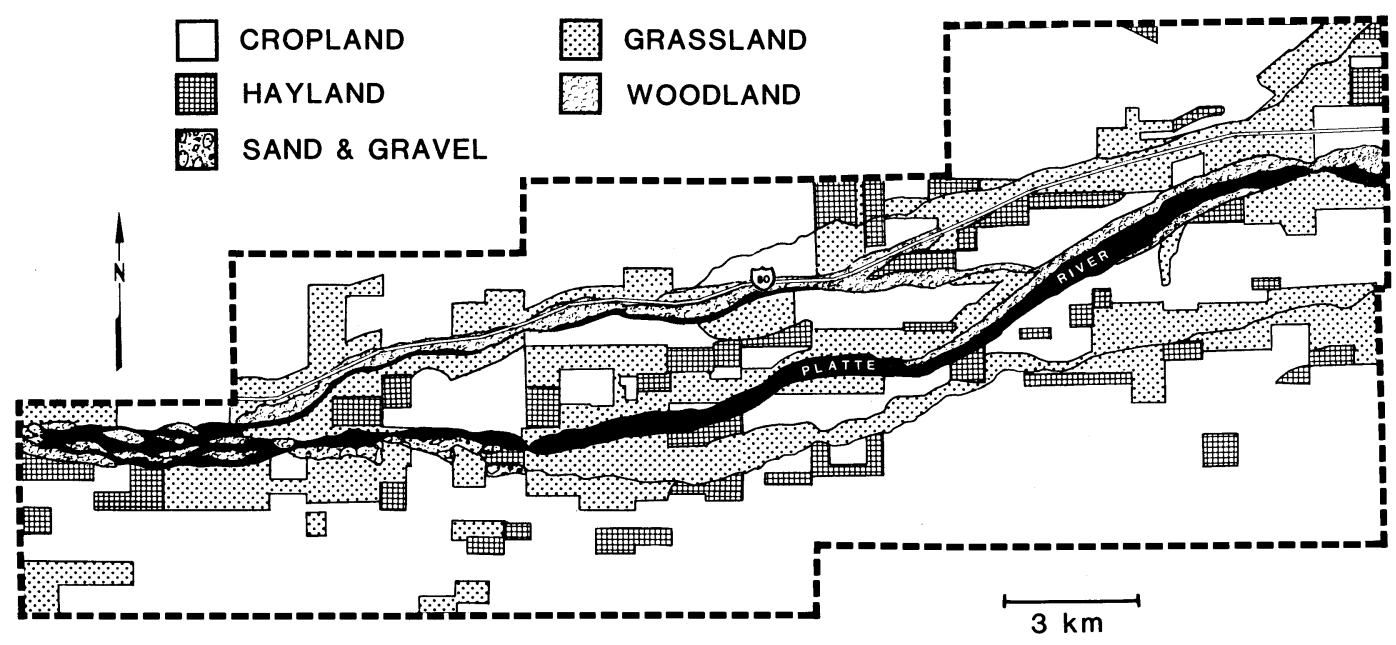

Fig. 2. Cover types and other features of the $267-\mathrm{km}^{2}$ tract used to study habitat use by radio-tagged sandhill cranes. The telemetry study area was located between Kearney and Shelton, Nebraska.

dissected by three channels of the river and Interstate Highway 80 (Fig. 2). Riparian woodlands and the river channels formed ribbons of natural habitat a few hundred meters to $1.5 \mathrm{~km}$ wide and constituted $12 \%$ of the telemetry study area. About 4,381 ha, or $17 \%$, of the area, was native grassland in $1979 ; 82 \%$ of the grassland was grazed, $7 \%$ was idle, and the remainder was cut for hay. Alfalfa and tame grasses composed 2,729 ha, or $11 \%$ of the area. About $54 \%$ of the telemetry area was cropland in 1979. During March 1979, $96 \%$ of the cropland was in corn of which $61 \%$ was stubble, $35 \%$ was tilled, and $4 \%$ had been plowed during the previous fall. The rest was in common milo, winter wheat, common soybeans, Sudan grass, and common oats. About $50 \%$ of the picked corn was grazed by livestock during the 1979-80 winter. Miscellaneous habitats composed 1,602 ha; lands altered by sand and gravel development were the most common component.

Cranes were trapped during late February and early March at several locations on the telemetry study area with rocketand cannon-projected nets. Silhouette and mounted decoys were used to attract cranes to capture sites in meadows and cornfields. Each of 20 cranes was weighed, aged as a juvenile or adult by head plumage (Lewis 1979), and marked with aluminum (USFWS) and yellow-coded, plastic leg bands and a back-mounted radio transmitter. After allowing an adjustment period of several days, individuals were located hourly each day from daybreak to dusk and locations recorded by triangulation from antenna-equipped vehicles. Detailed examination of habitat use was made by observing randomly selected unmarked cranes in each of the major habitats to determine the proportion of time cranes spent in various activities by habitat type. Activities were recorded at 12second intervals by using a metronome timing device (Wiens et al. 1970).

Nocturnal habitat use by sandhill cranes was studied by comparing habitat characteristics of used and unused channel sites between Kingsley Dam and Grand Island 
(Fig. 1). Measurements taken included (within each $0.8-\mathrm{km}$ segment) the width of present and former channel at midpoint, maximum channel width, total area of present and former river channel, presence of roads, number and type of power lines crossing the river, and presence of bridges. The predominant vegetation height-class ( $<0.5 \mathrm{~m}, 0.5-1.9 \mathrm{~m}, 2.0-3.9$ $\mathrm{m}, 4.0-7.9 \mathrm{~m}$, and $\geq 8.0 \mathrm{~m}$ ) (Currier 1982) along island shoreline and along both banks of the main channel was recorded for each segment and plotted on 1:24,000 USGS topographic maps. Areas of vegetation in each height-class within each 0.8 $\mathrm{km}$ river segment were measured from the topographic maps. Each river segment was assigned to one of three classes, based on maximum unobstructed channel width ( $\leq 50 \mathrm{~m}, 51-150 \mathrm{~m},>150 \mathrm{~m}$ ), and one of the five vegetative height-classes listed above. Unobstructed channel width refers to channel span uninterrupted by stands of woody vegetation. The number of cranes on each $0.8-\mathrm{km}$ river segment was estimated during aerial surveys conducted at dawn during 1978 and 1979 (Frith and Faanes 1982).

\section{RESULTS}

\section{Description of Staging Areas}

Sandhill cranes occupied three discrete areas encompassing about $1,019 \mathrm{~km}^{2}$ between Kingsley Dam and Grand Island (Fig. 1). The crane population was distributed as follows: 350,000 at staging area 1 ; 50,000 at staging area 2 ; and 100,000 at staging area 3 . About 4,000 additional cranes were located upstream from Kingsley Dam near Lewellen (U.S. Fish and Wildl. Serv., unpubl. data). Agriculture was the dominant land use on the principal staging areas (Table 1) with most lands managed for corn and cattle production. Most of the remaining lands were either
Table 1. Size of spring staging areas of sandhill cranes in Nebraska and their habitat composition.

\begin{tabular}{lrrr}
\hline & \multicolumn{3}{c}{ Staging area } \\
\cline { 2 - 4 } \multicolumn{1}{c}{ Character } & \multicolumn{1}{c}{1} & \multicolumn{1}{c}{2} & 3 \\
\hline Size $\left(\mathrm{km}^{2}\right)$ & 578 & 257 & 184 \\
Habitat type (\%) & & & \\
$\quad$ Cropland & 53 & 38 & 28 \\
Grassland & 23 & 20 & 40 \\
Hayland & 7 & 19 & 11 \\
Present channel & 3 & 3 & 2 \\
Former channel & 9 & 13 & 13 \\
$\quad$ (now shrubs and trees) & & & \\
Other & 5 & 8 & 6 \\
\hline
\end{tabular}

alfalfa hayland, river channel, or former river channel now covered with deciduous woodland. Willow (Salix spp.) and eastern cottonwood (Populus deltoides) were the pioneer arboreal species (Currier 1982). Deciduous woodland bordered the main channel throughout most of the three staging areas. Cattle grazed primarily in native pastures during the growing season and foraged in harvested cornfields during the remainder of the year. Alfalfa was grown to supply additional fodder for the livestock during the nongrowing season. Most of the cropland was irrigated from groundwater sources.

About $3 \%$ of the lands on staging areas were in public ownership. Public lands included the right-of-way for highway I-80 and adjacent lands managed as recreational sites. The only publicly owned land managed for the sandhill crane population was in staging area 3 which contained a 162-ha tract managed by the Nebraska Game and Parks Commission. Private conservation organizations managed tracts totaling about 2,189 ha on staging area 1 .

\section{Diurnal Habitat Use}

Ninety-seven percent of all hourly locations of radio-tagged cranes during spring 1978 and 1979 were in three hab- 
Table 2. Diurnal habitat use by radio-tagged sandhill cranes in the Platte River Valley, Nebraska, during spring 1978 and 1979 in comparison to habitats available. Numbers of crane locations are listed in parentheses.

\begin{tabular}{|c|c|c|c|}
\hline \multirow[b]{2}{*}{ Habitat type } & \multirow{2}{*}{$\underset{\substack{\text { Habitat } \\
\text { availability }}}{(\%)}$} & \multicolumn{2}{|c|}{ Crane habitat use $(\%)^{a}$} \\
\hline & & $1978^{c}$ & $1979^{c}$ \\
\hline \multicolumn{4}{|l|}{ Riverine } \\
\hline Unclassified & 11.6 & $0.1(1)$ & $1.9(35)$ \\
\hline \multicolumn{4}{|l|}{ Cropland } \\
\hline Corn-unclassified & & & $0.3(6)$ \\
\hline Corn stubble-ungrazed & 6.7 & $1.2(13)$ & $5.6(104)$ \\
\hline Corn-disced & 12.3 & $7.1(78)$ & $11.6(216)$ \\
\hline Corn-cultivated & 5.9 & $7.4(82)$ & $9.7(180)$ \\
\hline Corn-plowed & 2.0 & $1.5(17)$ & $1.1(20)$ \\
\hline Corn stubble-grazed & 25.0 & $27.3(302)$ & $31.9(594)$ \\
\hline Other & 2.2 & & $0.9(16)$ \\
\hline Total & 54.1 & $44.5(492)$ & $61.1(1,136)$ \\
\hline \multicolumn{4}{|l|}{ Native grassland } \\
\hline Grazed & 14.2 & $27.4(303)$ & $25.1(468)$ \\
\hline Mowed & 1.1 & $0.2(2)$ & $2.3(42)$ \\
\hline Idle & 1.2 & $0.3(3)$ & $0.4(8)$ \\
\hline Other & 0.8 & & $0.4(7)$ \\
\hline Total & 17.3 & $27.9(308)$ & $28.2(525)$ \\
\hline \multicolumn{4}{|l|}{ Tame hayland } \\
\hline Alfalfa-mowed & 5.3 & $19.4(215)$ & $7.6(142)$ \\
\hline Alfalfa-interseeded and mowed & 1.2 & $4.3(48)$ & $0.3(5)$ \\
\hline Tamegrass-mowed & 1.0 & $1.7(19)$ & $0.3(5)$ \\
\hline Tamegrass-grazed & 2.3 & $0.5(5)$ & $0.4(8)$ \\
\hline Other & 0.9 & $1.0(11)$ & $0.4(8)$ \\
\hline Total & 10.7 & $26.9(298)$ & $9.0(168)$ \\
\hline \multicolumn{4}{|l|}{ Miscellaneous } \\
\hline Farmsteads & 1.5 & & \\
\hline Sand and gravel development & 2.2 & & \\
\hline Other & 2.7 & $0.6(7)$ & \\
\hline Total & 6.4 & $0.6(7)$ & \\
\hline
\end{tabular}

a Mean number of locations/bird/year $=185 \pm 38(1978)$ and $133 \pm 49$ (1979)

b Habitat availability is based on an inventory conducted during late winter 1979 .

c $N=6$ cranes (1978) and 14 cranes (1979).

itat types: cropland, native grassland, and hayland. Cropland accounted for 45 and $61 \%$ of the locations during 1978 and 1979 , respectively (Table 2). In 1978, all cropland hourly fixes were in cornfields; $61 \%$ as grazed stubble, $36 \%$ as disced, cultivated, and plowed stubble, and $3 \%$ as ungrazed corn stubble (Table 2). During $1979,99 \%$ of cropland use was as cornfields, $52 \%$ as grazed stubble, $37 \%$ as disced, cultivated, and plowed stubble, $9 \%$ as ungrazed stubble, and $1 \%$ as unclassi- fied cornfields. Milo and winter wheat accounted for the remaining $1 \%$ of the cropland locations (Table 2).

Cranes spent $28 \%$ of the daylight hours in native grasslands during both 1978 and 1979. Ninety-eight and $89 \%$ of the crane locations in native grassland in 1978 and 1979 , respectively, were in grazed pastures, 1 and $8 \%$ in mowed meadows, 1 and $2 \%$ in idled grassland, and $1 \%$ in burned meadow (1979 only) (Table 2). Of 453 days of crane observation, individual 


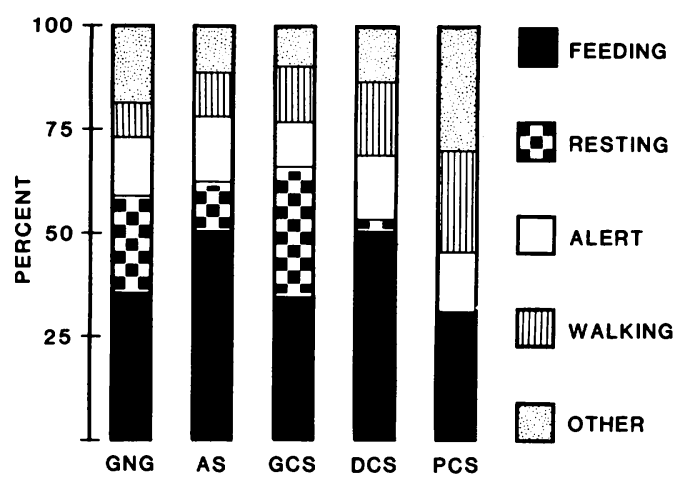

Fig. 3. Time budget of sandhill cranes by habitat type during spring along the Platte River. Habitat symbols are: GNG, grazed native grassland; AS, alfalfa stubble; GCS, grazed corn stubble; DCS, disced corn stubble; and PCS, plowed corn stubble.

cranes used native grasslands at least $73 \%$ of the days. Hayland use declined from 27 to $9 \%$ from 1978 to 1979 (Table 2). In 1978 and 1979,72 and $85 \%$ of the tame hayland locations were in mowed alfalfa fields with the remainder in various mixtures of alfalfa and tame grasses. Cranes seldom used the remaining miscellaneous habitats (Table 2). Crane use of sand and gravel development areas was not observed although these lands made up about $2 \%$ of the study area. Human disturbance and lack of adequate visibility for the cranes probably accounted for low use of most other habitats.

Cranes spent much of the daytime feeding and resting, on the basis of 125 hours of time budget observations obtained in 1978 (Fig. 3). Foraging accounted for the following proportions of the diurnal crane time budget (by habitat type): grazed native grassland (36\%), alfalfa stubble $(50 \%)$, grazed corn stubble (35\%), and disced corn stubble (51\%). Resting was most prevalent in grazed corn stubble and native grassland and occurred principally during midday. Cranes spent more time walking in disced (18\%) and plowed (25\%) cornfields than in grazed corn stubble (14\%), probably due to the greater searching effort required to locate corn kernels at the former sites. In Texas, a single discing of corn stubble has been shown to make $93 \%$ of the corn kernels unavailable and plowing 99\%, whereas availability of kernels to waterfowl increased $7 \%$ with grazing (Baldassarre et al. 1983).

\section{Nocturnal Habitat Use}

River channel conditions influenced sandhill crane distribution at night. Early arriving flocks often encountered an icecovered channel and roosted on nearby flooded meadows. As channel habitat became available, most cranes shifted to river roosts. Cranes roosted in about $111 \mathrm{~km}$ of the river channel. Mean unobstructed channel width and channel area varied widely among the sections of river, and crane use was greatest where channels were widest (Table 3). The widest channels were located between Kearney and Grand Island and the narrowest between the Tri-County Diversion Dam and Overton. Width variations reflect long-term effects of differences of flows among the reaches caused by diversion and irrigation return flowages. Only about 493 million $\mathrm{m}^{3}$ (400,000 acre-feet) pass through the channel near Brady annually. The addition of 660 million $\mathrm{m}^{3}$ (533,000 acre-feet) of power generation return flows from the Tri-County Canal near Overton is partially responsible for the wider channels in sections 3 and 4 (Table 3). Mean vegetation heights on islands and along edges of the channel reflect the extensive development of woody vegetation that has accompanied channel shrinkage (Table 3 ).

Almost $70 \%$ of all roosting cranes observed were in $0.8-\mathrm{km}$ segments having an unobstructed channel at least $150 \mathrm{~m}$ wide, even though only $25 \%$ of the river seg- 
Table 3. Distribution of sandhill cranes in relation to channel characteristics along four sections of the Platte and North Platte rivers lying between the Kingsley Dam site and Grand Island, Nebraska.

\begin{tabular}{|c|c|c|c|c|c|c|c|c|c|c|c|}
\hline & \multirow[b]{3}{*}{ River section } & \multirow{3}{*}{$\begin{array}{c}\text { Distance } \\
(\mathrm{km})\end{array}$} & \multirow{3}{*}{$\begin{array}{l}\text { Estimated } \\
\text { no. cranes }\end{array}$} & \multicolumn{8}{|c|}{ Channel characteristics $/ 0.8 \mathrm{~km}$} \\
\hline & & & & \multicolumn{2}{|c|}{$\begin{array}{c}\text { Channel } \\
\text { width (m) }\end{array}$} & \multicolumn{2}{|c|}{$\begin{array}{l}\text { Channel } \\
\text { area (ha) }\end{array}$} & \multicolumn{2}{|c|}{$\begin{array}{c}\text { Island } \\
\text { vegetation } \\
\text { height-class }\end{array}$} & \multicolumn{2}{|c|}{$\begin{array}{c}\text { Bank } \\
\text { vegetation } \\
\text { height-classa }\end{array}$} \\
\hline & & & & $\overline{\bar{x}}$ & SD & $\overline{\bar{x}}$ & SD & $\overline{\bar{x}}$ & SD & $\overline{\mathbf{x}}$ & SD \\
\hline (1) & $\begin{array}{l}\text { Kingsley Dam to Tri-County } \\
\text { Diversion Dam (North } \\
\text { Platte) }\end{array}$ & 87.1 & $93,651^{\mathrm{b}}$ & 83.5 & 37.9 & 17.9 & 5.9 & 3.4 & 1.6 & 3.6 & 1.2 \\
\hline (2) & $\begin{array}{l}\text { Tri-County Diversion Dam } \\
\text { (North Platte) to } \\
\text { Tri-County Diversion } \\
\text { Discharge (Overton) }\end{array}$ & 97.6 & 0 & 51.5 & 28.5 & 11.4 & 7.5 & 2.9 & 2.3 & 4.6 & 0.7 \\
\hline (3) & $\begin{array}{l}\text { Tri-County Diversion } \\
\text { Discharge (Overton) to } \\
\text { Highway } 44 \text { Bridge } \\
\text { (Kearney) }\end{array}$ & 51.6 & $57,156 \pm 36,589^{\mathrm{c}}$ & 141.4 & 55.5 & 39.2 & 6.7 & 4.6 & 1.0 & 4.4 & 1.0 \\
\hline (4) & $\begin{array}{l}\text { Highway } 44 \text { Bridge (Kearney) } \\
\text { to Highway } 281 \text { Bridge } \\
\text { (Grand Island) }\end{array}$ & 62.9 & $386,063 \pm 37,151$ & 182.5 & 54.1 & 43.0 & 8.5 & 3.7 & 1.2 & 4.1 & 1.0 \\
\hline
\end{tabular}

a Predominant height-class of shoreline vegetation: $1=<0.5 \mathrm{~m} ; 2=0.5-1.9 \mathrm{~m} ; 3=2.0-3.9 \mathrm{~m} ; 4=4.0-7.9 \mathrm{~m}$; and $5=\geq 8.0 \mathrm{~m}$

b Unpubl. data, U.S. Fish and Wildlife Service. The estimate of the number of cranes in reach 1 is based on a ground count on 26 March 1980

${ }^{c}$ Unpubl. data, U.S. Fish and Wildlife Service. Estimates of crane numbers in reaches 3 and 4 were obtained on 4 April 1980 by using an aerial photographic sampling technique described by Ferguson et al. (1979) 


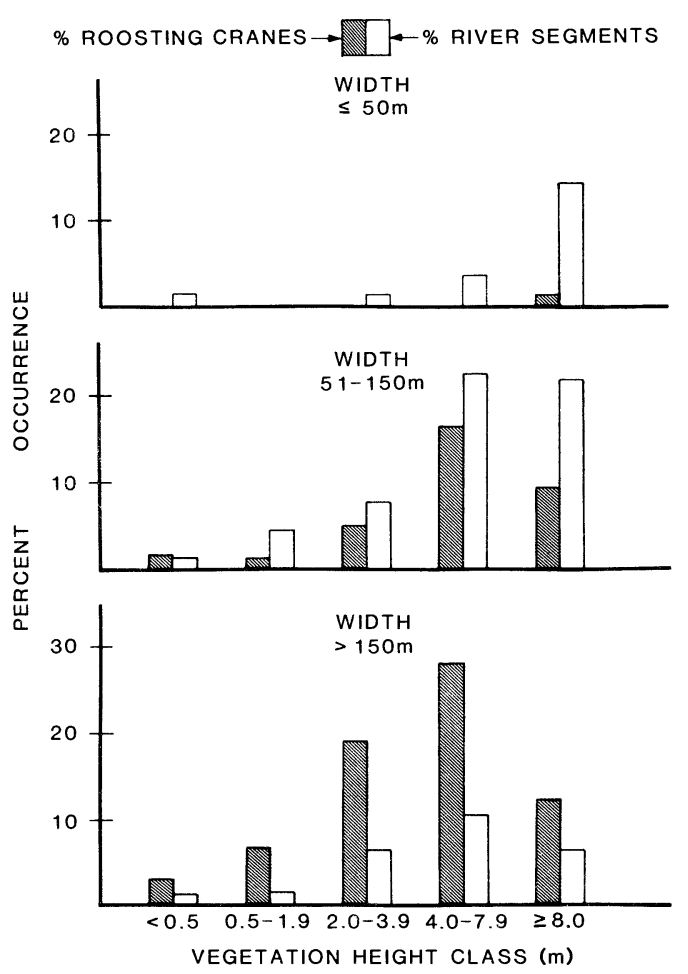

Fig. 4. Distribution of roosting sandhill cranes (by percent occurrence) among categories of unobstructed channel width and predominant vegetation height-class on adjacent channel and island banks.

ments had channels this wide (Fig. 4). Over $99 \%$ of all roosting cranes were observed in river segments with channels over $50 \mathrm{~m}$ wide; this included $82 \%$ of all segments between Kingsley Dam and Grand Island.

Vegetation height adjacent to the river channel apparently influenced roosting distribution. For all vegetation heightclasses except the tallest $(\geq 8.0 \mathrm{~m})$, the percentage of cranes roosting on river segments exceeded the percentage availability of that segment class (Table 4). However, vegetation height was not as important as open channel width. When the two factors are combined, the relationship is more easily understood. Chi- square analysis strongly rejected $(P<$ 0.001 ) the null hypothesis that cranes used the 385 river segments independently of width and vegetation height. Cranes seldom used river channel segments where the widest available open channel was $\leq 50$ $\mathrm{m}$, regardless of vegetation height (Fig. 4). Although over $18 \%$ of the $0.8-\mathrm{km}$ segments were in this width-class, only $0.2 \%$ of the cranes were found there. River segments having maximum channel widths of 51-150 m were used more frequently by roosting cranes, but usage exceeded availability only where the vegetation was shorter than $0.5 \mathrm{~m}$. Cranes selected river segments with open channels wider than $150 \mathrm{~m}$, regardless of vegetation height.

The distribution and density of roosting cranes were also influenced by proximity to human activity. Bridges and roads immediately adjacent to the river had a strong negative effect on crane usage ( $\mathrm{Ta}$ ble 5). The mean number of cranes roosting on river segments with bridges, adjacent roads, or both, was less than half the usage on segments without these features. Sixty-two of the $0.8-\mathrm{km}$ river segments had a bridge or an adjacent road.

\section{DISCUSSION}

Several factors have contributed to the Platte and North Platte river valleys becoming the principal spring staging areas for the midcontinent population of sandhill cranes. High quality roosting and feeding habitat centrally located in the migration corridor has long provided suitable conditions for cranes. The banning of spring shooting of cranes and other migratory birds in 1918 under the terms of the Migratory Bird Treaty Act, and its subsequent effective enforcement, removed a key source of disturbance. Large farming operations, fenced fields, and trespass laws restricting access to private lands have discouraged human activity in 
Table 4. The distribution of sandhill cranes (by percent) roosting in the channel of the Platte and North Platte rivers, Nebraska, in relation to vegetative height on adjacent shorelines and islands (upper row). The percent of river segments representing each vegetation height category is listed below.

\begin{tabular}{cccccc}
\hline & \multicolumn{5}{c}{ Vegetation height-class $^{\mathrm{a}}(\mathrm{m})$} \\
\cline { 2 - 6 } Variable & $<0.5$ & $0.5-1.9$ & $2.0-3.9$ & $4.0-7.9$ & $\geq 8.0$ \\
\hline Sandhill cranes & 4.3 & 7.1 & 23.3 & 44.5 & 20.9 \\
River segments & 2.6 & 5.8 & 14.3 & 36.1 & 41.3 \\
\hline
\end{tabular}

${ }^{\text {a }}$ Mean height-class of predominant vegetation height on north, south, and island banks.

areas used by cranes. Loss of habitat elsewhere along the migration route probably has also contributed to increased use of the Nebraska staging areas.

The current distribution of sandhill cranes along the Platte and North Platte rivers is primarily a function of channel habitat conditions. Sandhill cranes continue to roost where the channel remains relatively open and avoid segments with channel widths $<50 \mathrm{~m}$ wide. Avoidance of narrow channels by cranes has also been observed in Oklahoma. Lewis (1976) reported that cranes stopped using the Goodwin-Young roosts on the Salt Fork of the Red River during the winter of 196970 when encroaching French tamarisk (Tamarix gallica) constricted most of the stream channel to $<100 \mathrm{~m}$. Sandhill cranes generally favor roosts only when flooded (Lovvorn and Kirkpatrick 1981) but will temporarily roost on dry land (Lewis 1976, Melvin 1978, this study) when channel or other wetland sites are not available. Sites lacking a water barrier, however, do not provide secure roosting habitat for staging cranes.

Sandhill cranes spent about half of the daylight hours in cornfields. High use of cornfields was associated with extensive feeding on waste corn. Over $90 \%$ of the birds' energy requirements while in Nebraska are obtained from corn (K. J. Reinecke, unpubl. data). Similar high use of unplowed cornfields has been reported for the eastern population of greater sandhill cranes on their primary spring staging area in Indiana (Lovvorn and Kirkpatrick 1982).

Grazed native pastures were used extensively for feeding and resting in $\mathrm{Ne}-$ braska. Cranes forage in pastures to obtain terrestrial invertebrates (Reinecke and Krapu 1979). Ungrazed idle stands of grasses were usually avoided by cranes, presumably because of reduced visibility. We observed, however, that ungrazed tracts of big bluestem (Andropogon gerardi), switchgrass panicum (Panicum virgatum), and yellow Indiangrass (Sor-

Table 5. The relationship between roads or bridges, channel width, and height of bank vegetation and sandhill crane roosting densities along the Platte and North Platte rivers, Nebraska.

\begin{tabular}{lc}
\hline & $\begin{array}{c}\text { Density } \\
\left(\begin{array}{c}\bar{x} \\
\text { (cranes/ha })^{\mathrm{a}}\end{array}\right.\end{array}$ \\
\hline Roads or bridges & \\
Absent & 82.0 \\
Present & 38.3 \\
Channel width & \\
$\leq 50 \mathrm{~m}$ & 1.9 \\
$51-150 \mathrm{~m}$ & 61.2 \\
$>150 \mathrm{~m}$ & 158.4 \\
Height of bank vegetation ${ }^{\mathrm{b}}$ & \\
$<0.5 \mathrm{~m}$ & 125.3 \\
$0.5-1.9 \mathrm{~m}$ & 66.9 \\
$2.0-3.9 \mathrm{~m}$ & 98.5 \\
$4.0-7.9 \mathrm{~m}$ & 113.1 \\
$\geq 8.0 \mathrm{~m}$ & 31.5 \\
\hline
\end{tabular}

a Mean of maximum roosting densities (cranes per ha of open water) of all $0.8-\mathrm{km}$ segments in category.

$\mathrm{b}$ Mean height-class of predominant vegetation on north, south, and
of all $0.8-\mathrm{km}$ segments in category. island banks within $0.8-\mathrm{km}$ segment. 
ghastrum nutans) received heavy use immediately after the old growth was removed by burning in early spring. Cranes collected at burn sites had fed principally on earthworms (K. J. Reinecke, pers. commun.), which were abundant in upper soil strata.

Use of alfalfa hayland by cranes was more variable than that of native grassland and cornfields. Annual variations in usage may have been caused by differences in earthworm availability near the soil surface. Although cranes feeding in native grasslands consume a diverse diet of invertebrate foods including forms largely immobile, cranes in hayland were restricted principally to earthworms (Reinecke and Krapu 1979). The decline in hayland use in 1979 may partially be related to diminished availability of earthworms in the upper soil strata because of drought.

\section{MANAGEMENT CONSIDERATIONS AND RESEARCH NEEDS}

Existing information suggests that adequate habitat existed along the Platte and North Platte rivers during the study period to satisfy critical needs of the present crane population of about one-half million birds. This conclusion stems from knowledge that cranes acquired substantial fat reserves while there (G. L. Krapu, unpubl. data) and population survey data that suggest a stable or growing population (U.S. Fish and Wildl. Serv., unpubl. data). The present high densities of cranes using available roost sites and ongoing plans to divert much of the remaining unappropriated flows (Krapu et al. 1982) indicate a need for measures to limit further loss of channel habitat. Failure to curb habitat degradation would prompt additional crowding and subject the crane population to an increased risk of disease outbreaks and other forms of mortality and could ultimately lead to loss of the Platte River as a crane staging area.

Maintenance of a $>150$-m-wide unobstructed main channel to provide suitable roosting habitat for the crane population will require the development of techniques effective in controlling woody vegetation. Designation of part of the existing unappropriated flows for channel maintenance is needed to assure a dependable source of water to scour away seeds and new seedlings of woody plants before root systems are sufficiently developed to withstand flooding. The minimum flow necessary to maintain a channel width of about $150 \mathrm{~m}$ at Overton has been estimated to be $108 \mathrm{~m}^{3} /$ second for at least 16 days from May through August, with discharges spaced to inhibit germination of both early and late falling seeds (Karlinger et al. 1981). Sufficient flows are also needed during the staging interval to inundate the channel and provide secure roost sites. Preliminary testing suggests that mechanical and chemical methods may also have potential application in controlling woody vegetation ( $P$. J. Currier, unpubl. data), but further research will be needed to fully interpret and implement these findings.

Vegetation on lands used by the cranes during the daylight hours should be maintained in a moderate to low stage of growth during the stop-over interval. Most privately owned grasslands, haylands, and cropland meet this criterion under present management. Habitat conditions on the staging areas should be monitored regularly to provide for detection of major changes in land use that could be detrimental to the crane population. A change from the present corn-livestock economy, for example, could severely reduce the capacity of the Platte Valley to support cranes. Native grasslands in the Valley are currently being converted to cropland at 
a rapid rate (Krapu et al. 1982). To assure a sufficient habitat base in the future to adequately meet the requirements of the crane population may necessitate placing some restrictions on land use in areas bordering major roosts. We recommend the use of conservation easements that would allow most current land-use practices to continue while preventing changes incompatible with crane usage as the primary means of protecting habitat on the staging areas. In addition, some strategically located tracts should be acquired in fee title to help meet the needs of the crane population. These intensively managed areas could include facilities for the public to observe the cranes in a setting that would minimize disturbance to the birds and help reduce disruptions to private landowners resulting from the growing influx of people seeking to view the cranes.

\section{LITERATURE CITED}

Baldassarke, G. A., R. J. Whyte, E. E. Quinlan, AND E. G. Bolen. 1983. Dynamics and quality of waste corn as waterfowl food in Texas. Wildl. Soc. Bull. 11:25-31.

Currier, P. J. 1982. The floodplain vegetation of the Platte River: phytosociology, forest development, and seedling establishment. Ph.D. Thesis, Iowa State Univ., Ames. 332pp.

FaAnes, C. A., AND A. M. Frank. 1982. Characteristics of diurnal sandhill crane flocks in the Platte River Valley, Nebraska. Pages 22-26 in J. C. Lewis, ed. Proc. 1981 Crane Workshop. Natl. Audubon Soc., Tavernier, Fla.

Ferguson, E. L., D. S. Gilmer, D. H. Johnson, N. Lyman, AND D. S. Benning. 1979. Experimental surveys of sandhill cranes in Nebraska.
Pages 41-49 in J. C. Lewis, ed. Proc. 1978 Crane Workshop. Colorado State Univ., Fort Collins.

Frith, C. R., AND C. A. FAANES. 1982. Inventory of sandhill crane roosting habitat on the Platte and North Platte Rivers, Nebraska. Pages 13-16 in J. C. Lewis, ed. Proc. 1981 Crane Workshop. Natl. Audubon Soc., Tavernier, Fla.

Karlinger, M. R., R. C. Mengis, J. E. Kircher, AND T. R. ESCHNER. 1981. Application of theoretical equations to estimate the discharge needed to maintain channel width in a reach of the Platte River near Lexington, Nebraska. U.S. Geol. Surv. Open-File Rep. 81-697. 16pp.

Krapu, G. L., K. J. Reinecke, and C. R. Frith. 1982. Sandhill cranes and the Platte River. Trans. North Am. Wildl. and Nat. Resour. Conf. 47:542-552.

LEWIS, J. C. 1976. Roost habitat and roosting behavior of sandhill cranes in the southern central flyway. Pages 93-104 in J. C. Lewis, ed. Proc. Int. Crane Workshop. Oklahoma State Univ., Stillwater.

. 1979. Field identification of juvenile sandhill cranes. J. Wildl. Manage. 43:211-214.

Lovvorn, J. R., AND C. M. Kirkpatrick. 1981. Roosting behavior and habitat of migrant greater sandhill cranes. J. Wildl. Manage. 45:842-857.

, AND 1982 . Field use by staging eastern greater sandhill cranes. J. Wildl. Manage. 46:99-108.

MELvin, S. M. 1978. Ecology of non-breeding Wisconsin sandhill cranes, with emphasis on crop damage and migration. M.S. Thesis, Univ. Wisconsin, Stevens Point. 80pp.

Reinecke, K. J., AND G. L. KRapu. 1979. Spring food habits of sandhill cranes in Nebraska. Pages 13-19 in J. C. Lewis, ed. Proc. 1978 Crane Workshop. Colorado State Univ., Fort Collins.

Wiens, J. A., S. G. Martin, W. R. Holthaus, and F. A. IWEN. 1970. Metronome timing in behavioral ecology studies. Ecology 51:350-352.

Williams, G. P. 1978. The case of the shrinking channels - the North Platte and Platte rivers in Nebraska. U.S. Geol. Surv. Circ. 781. 48pp.

Received 31 January 1983.

Accepted 11 August 1983. 